TI 2012-080/3

Tinbergen Institute Discussion Paper
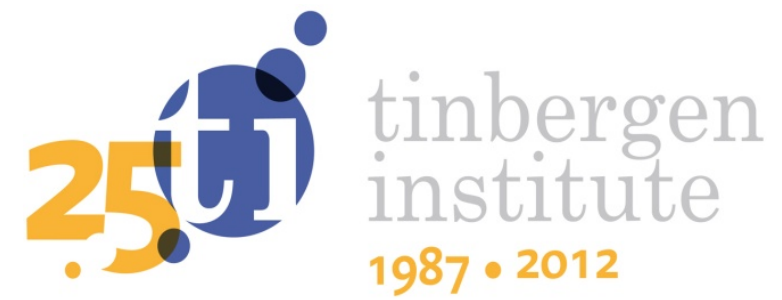

\title{
The Educational Bias in Commuting
} Patterns:

\section{Micro-Evidence for the Netherlands}

\author{
Stefan P.T. Groot \\ Henri L.F. de Groot ${ }^{1,2}$ \\ Paolo Veneri3
}

\footnotetext{
' Faculty of Economics and Business Administration, VU University Amsterdam, and Tinbergen Institute;

2 Ecorys NEI;

3 OECD, Paris.
} 
Tinbergen Institute is the graduate school and research institute in economics of Erasmus University Rotterdam, the University of Amsterdam and VU University Amsterdam.

More TI discussion papers can be downloaded at http://www.tinbergen.nl

Tinbergen Institute has two locations:

Tinbergen Institute Amsterdam

Gustav Mahlerplein 117

1082 MS Amsterdam

The Netherlands

Tel.: +31(0)205251600

Tinbergen Institute Rotterdam

Burg. Oudlaan 50

3062 PA Rotterdam

The Netherlands

Tel.: +31(0)10 4088900

Fax: $+31(0) 104089031$

Duisenberg school of finance is a collaboration of the Dutch financial sector and universities, with the ambition to support innovative research and offer top quality academic education in core areas of finance.

DSF research papers can be downloaded at: http://www.dsf.nl/

Duisenberg school of finance

Gustav Mahlerplein 117

1082 MS Amsterdam

The Netherlands

Tel.: +31(0)20 5258579 


\title{
The educational bias in commuting patterns
}

\section{Micro-evidence for the Netherlands}

\author{
Stefan Groot ${ }^{\mathrm{a}}$, Henri L.F. de Groot ${ }^{\mathrm{a}, \mathrm{b}, \mathrm{c}}$ and Paolo Veneri ${ }^{\mathrm{d}, 1}$ \\ ${ }^{a}$ Dept. of Spatial Economics, VU University Amsterdam, The Netherlands \\ ${ }^{\mathrm{b}}$ Tinbergen Institute, Amsterdam-Rotterdam, The Netherlands \\ ${ }^{\mathrm{c}}$ Ecorys NEI, Rotterdam, The Netherlands \\ ${ }^{\mathrm{d}}$ Regional Development Policy Division (GOV/RDP), OECD, Paris, France
}

\begin{abstract}
This study analyses the relation between education and commuting behaviour of Dutch workers. Results show that, ceteris paribus, higher educated workers commute further, both in terms of distance and time. In addition, higher educated workers are more frequent users of public transport and of bicycles. Furthermore, we find that higher educated workers are relatively more likely to commute towards agglomerated areas and areas that pay relatively high wages, while they are more likely to live in and commute from areas with higher land rents.
\end{abstract}

Keywords: commuting, education, urban amenities, agglomeration JEL codes: $\mathrm{R} 12, \mathrm{R} 21, \mathrm{R} 23$

\footnotetext{
${ }^{1}$ We are grateful to Jos van Ommeren for valuable comments on an earlier version of this paper. Financial support of NICIS is gratefully acknowledged. This research heavily draws on micro data made available by Statistics Netherlands.
} 


\section{Introduction}

The past few decades have been characterized by several socioeconomic changes with important consequences for patterns of travel behavior and residential location. Many economic and residential activities have decentralized from old centers to the suburbs of metropolitan and urban areas, and people have begun to travel - on average - longer distances than in the past. Commuting time, in contrast, has remained rather constant, because workers use increasingly faster modes of transport. This phenomenon is known as the 'commuting time paradox' (Van Ommeren and Rietveld, 2005). Of a relatively recent date is a revival of cities with attractive amenities, which seem to be particularly attractive for high-skilled people (e.g., Glaeser and Saiz, 2004; Glaeser, 2011). These trends are related to a complex set of developments that occurred in the last few decades, among which are the increase in per capita income (which may shift demand for housing towards larger houses in the suburbs), an increase in the number of part-time workers and two-earner households, and the wide diffusion of private cars and technological progress which is most visible in the advent of ICT.

The increase in per capita income and in the number of workers - where the latter is also related to the increase in female participation rates - are important aspects to be taken into account to understand the changing commuting patterns. These facts have made time scarcer, inducing individuals to trade-off money for time (Levinson and Kumar, 1995). This need for substitution, in turn, has increased the number of transactions and the consequent need to travel, affecting both localization patterns and individual travel behavior. At the same time, the income elasticity of demand for housing may increase commuting time because individuals with higher incomes want to live in more spacious housing. As argued by Rouwendal and Nijkamp (2004), commuting is the result of a network economy in which individuals look for earning opportunities outside their place of residence. As a matter of fact, the spatial organization of earning capabilities - the physical separation between home and fulfilling workplaces - and individual characteristics are the main determinants of commuting patterns.

Travel behavior is affected by both individual attributes and characteristics of the context in which individuals live. Among the individual attributes that are thought to influence travel patterns, education has been often included in empirical analyses as a mere control in order to disentangle the role of other attributes. The goal of this paper is to understand the role of education as a determinant of differences in travel behavior across individuals in the Netherlands. The empirical literature shows with substantial clarity that more educated 
workers commute longer and further than low-skilled workers. However, explanations are scarce. Moreover, given the fact that average education is increasing, the implications in terms of the spatial dimension of the labor market and the connected commuting patterns are worth investigating.

The reasons why education can play a role in explaining differences in travel behavior are diverse. In fact, investments in human capital can strongly influence both job and home location. Search frictions in both the labor market and the housing market may be related to the level of education. As higher educated workers are more likely to own, rather than rent housing, residential mobility is likely to be lower. This results - ceteris paribus - in longer commutes. On the labor market, search frictions could be relatively high for higher educated workers because of the more specialized nature of their work, which would again increase commuting time. Another reason why commuting distance and time might be higher for more educated workers is that educated people are more willing to travel longer distances to realize their human capital investments as well as their professional expectations. Moreover, higher educated people are on average paid more than low-skilled workers, such that the choice of residence could be also influenced by the desire to live in higher quality houses in the lowdensity hinterland of urban areas. The fact that the largest Dutch cities have a relatively high share of social housing is likely to contribute to this. The full set of factors at the base of the role of education for travel behavior are analyzed in the following sections, trying to disentangle the role of individual attributes from that of the spatial characteristics of the places of residence and work.

The empirical part of this paper is aimed at finding empirical evidence on the specific role of education on commuting patterns, trying also to disentangle such a role from the effect of higher wages. In fact, despite the always-present correlation between the level of education and the wage of workers, education could have a specific role in terms of commuting behavior that goes beyond its effect on wages. Differences in commuting patterns between well-paid and well-educated workers may occur for several reasons. First, the spatial extent of the job-search area is wider for highly educated workers, since they are relatively more likely find a fulfilling job when travelling further relative to lower educated workers. This is because the job market for highly educated workers is more concentrated in large urban centers. Second, highly educated workers may prefer to use public means of transport, since they have the possibility to carry out part of their work during the trip. The successful introduction of Office Buses in some countries, like in Finland, is useful to understand that there is a value in the possibility to work during the commute. 
It is also possible that the higher use of public transport by higher educated workers is to some extent institutionalized. Many public institutions (such as universities), promote the use of public transport among their employees. While there is often no compensation for the use of personal cars, these public institutions fully or partially compensate their employees when they use public transport for their commutes. As the share of higher educated workers is somewhat higher in the public sector compared to the market sector, this would result in a positive correlation between level of education and the use of public transport.

The remainder of this paper is structured as follows. Section 2 reviews the literature on the determinants of commuting behavior, as well as previous findings about the role of education. Theories that help to interpret the reason behind the role of education for commuting are also discussed in this section. Section 3 describes our dataset and presents commuting patterns in the Netherlands and some stylized facts about the differences between commutes of higher and lower educated workers. Section 4 specifies the empirical settings that are employed in order to understand the implications of education for commuting patterns and the factors explaining these differences. Section 5 gives some concluding remarks, and discusses possible policy implications.

\section{Related literature and theoretical background}

The link between individual education level and commuting behavior is complex, especially if mode choice, distance travelled and time spent travelling are all taken into account simultaneously. There is quite a large amount of scientific work that investigates the role of individual attributes on commuting behavior. Compared with other non-individual characteristics, such as spatial structure, housing markets, and the balance between jobs and residents, individual attributes seem to account for a large part of commuting behavior (Giuliano and Small, 1993). Among these individual attributes, the level of education has often been included as a control, but its nature and the implications of its role have rarely been discussed in detail.

The empirical literature devoted to understanding the determinants of commuting behavior finds that a higher level of education is associated with longer trips in terms of distance (Lee and McDonald, 2003; Papanikolaou, 2006; Vance and Hedel, 2008; Prashker et al., 2008). Similar results are found with regard to commuting time (Lee and McDonald, 2003; Shen, 2000). More specifically, Shen (2000) finds that highly educated people travel longer while low-educated people tend to work closer to home. In addition, it has been 
argued that highly educated people have a higher probability to be long-distance commuters (Öhman and Lindgren, 2003). This may be explained from the fact that the disutility associated with distance travelled is smaller for the highly educated (Rouwendal, 2004).

On the other hand, by taking into account alternative modes of transport, Burbidge et al. (2006) and Coogan (2003) show that highly educated individuals walk significantly more than poorly-educated ones. Dieleman et al. (2002) in their analysis of Dutch commuting patterns find that more educated people are more likely to use private cars for their commutes. They also find that education is relatively more important for shopping trips than for work related commutes, since shopping activities are more affected by the type of residential environment. Hence, higher educated workers - which tend to live in the residential suburbs - travel on average longer distances than people living in more central and more shop-served locations. Furthermore, they find that the most educated people travel longer distances by public transport for leisure activities. On the whole, the positive association between the level of education and the length of the commute - both in terms of time and distance travelled - is almost a stylized fact in the empirical literature.

\section{Understanding the role of education}

In order to understand the role of individual education on commuting patterns, many factors should be taken into account. The distance and time travelled depend on residential and work location, both of which are chosen by individuals. Some studies have investigated these individual choices using a joint utility approach that considers choices among combinations of residence and job localizations that maximize individual income (Yapa et al., 1971). Put differently, this approach explains commuting behavior as the minimization of commuting and migration costs, given a certain income level.

As the Dutch housing market is relatively regulated, the costs of migration are relatively high, thus positively affecting commuting distance and time. However, a possible shortcoming of this hypothesis is that the bulk of workplaces are located within cities, so that the choice of work location is particularly bounded by the localization of firms. In addition, commuters are not identical and individual characteristics are central in explaining observed travel behavior. Of particular importance in the Netherlands are relatively high transaction costs on residential mobility.

Van Ommeren and Van Leuvensteijn (2005) have estimated that a 1 percent-point increase in transaction costs decreases residential mobility rates by at least 8 percent, the 6 percent ad valorem tax on buying housing (reduced to 2 percent in 2011) is likely to have 
resulted in a substantial reduction of the mobility of house owners. As this increases the costs of reducing commuting time by changing residential location, this is likely to result in higher commuting time. As higher educated workers are more likely to own a house relative to lower educated workers (see, for example, Hood, 1999), this is likely to increase the average commuting time of higher educated workers relative to the lower educated.

The joint utility approach does not provide an explanation for excess commuting, e.g. the phenomenon that actual commuting is substantially larger than the amount of commuting that would be optimal given the spatial distribution of the quality of housing and jobs. Van Ommeren and Van der Straaten (2008) estimate that excess commuting due to search imperfections account for about half of total commuting. Because of imperfect information regarding all available jobs, workers will regularly accept a job at a certain location that does not optimize their wage and commuting costs, because they do not know if and when better job offers will arrive. As the activities of higher educated workers tend to be more specialized relative to those of lower educated workers, it is likely that the job arrival rate will be lower for more educated people, which will result in a suboptimal match and thus higher commuting distance and time.

The spatial distribution of activities within regions and urban areas can contribute significantly to explaining the role of education in commuting patterns. In fact, it has been argued that the central cities within metropolitan areas remain to have a good accessibility to less educated jobs, even in those regions that experienced a drastic decentralization of jobs (Shen, 1998). In addition, graduates are becoming less spatially mobile, in the sense that they migrate less toward other regions in order to find a job. However, this trend is mainly explained by macroeconomic factors such as regional economic development rather than by a changing role of education for individuals (Venhorst et al., 2011).

Regarding individual characteristics, a higher level of education is associated with a higher income, which in turn has been found to be correlated with longer trips (Giuliano and Small, 1993). Besides being related to income, education is related with the spatial scale of individuals' social networks and with the area of job search (Holzer, 1987; Wilson, 1987). Educated individuals carry out their daily activities, including the choice of jobs and the related commuting, in a wider space. In addition, it has been argued that well educated individuals travel longer distances because they look for more desirable residential locations, paying relatively less attention to the length of the travel (Prashker et al., 2008). In other words: as the level of education increases, the sensitivity to the distance travelled decreases due to residential preferences. An additional cause for the longer commutes of well-educated 
individuals is that people with a higher level of education are more likely to find interesting and gratifying jobs, hence they can accept a longer travel (Ory et al., 2004). As a matter of fact, they value the travel to work less than people with low education levels. Consistently with this idea, Giuliano (1989) argues that education may influence home locations and the ability to absorb transportation costs.

\section{Data and stylized facts}

The empirical part of this paper builds upon linked micro data from Statistics Netherlands (CBS). The source for data on worker and job characteristics (except for wages) and commuter behavior are the 2000 to 2008 cross-sections of the Dutch labor force survey (EBB, Enquête Beroeps Bevolking). As wages are not available through the labor force survey, we have used data from the Dutch tax authority (compulsory employer reported), which is available through the CBS Social Statistics database (SSB, Sociaal Statistisch Bestand). For workers with multiple jobs, we include only the (self reported) most important job. The CBS consumer price deflator (CPI, Consumenten Prijs Index) has been used to deflate wages. For most of the analysis in this paper, we use the natural logarithm of real pretax hourly wages. Due to methodological revisions of both SSB and EBB, there is a discontinuity between 2005 and 2006, though its effect on outcomes seems to be minor. It is important to note that wages do not include compensation for travel expenses. ${ }^{2}$

To make sure that only workers with a sufficiently strong attachment to the labor market are included, we have dropped some observations. Workers must be aged 18-65, and work at least 12 hours per week. ${ }^{3}$ We have dropped all observations with an hourly wage less than 10 percent of the median hourly wage. Such observations are unlikely to be regular wages, as they are below the minimum wage. Worker characteristics are the level of education (we can distinguish eight different levels), age, municipality of residence, country of birth (a binary variable that indicates whether a worker is born in the Netherlands or not), gender, and whether a worker is employed part-time or full-time. For each job, the municipality where the employee works is available, as well as the industry (we use the 2-digit NACE industry). On the commute of each worker, we have data on the (self reported) mode of transport, average

\footnotetext{
${ }^{2}$ If we would have included employers compensation for travel expenses, this would have resulted in several econometric issues. As many employers in the Netherlands compensate employees for their commuting expenses, this would result in a spurious regression when, for example, estimating the relation between wages and commuting distance.

${ }^{3}$ Statistics Netherlands defines workers with a working week of at least 12 hours as employed, workers with a working week of at least 36 hours are considered full-time employees. Jobs occupied by teenagers are often side-line jobs that would be outliers in our dataset.
} 
travel distance and travel time. The resulting dataset of nine cross-sections contains 154,238 observations (an average of 17,138 per year).

\section{Commuting distance and time}

Table 1 presents descriptive statistics concerning the variables that are related to commuting behavior. The average distance of a (one-way) commute is 17 kilometers, the average commuting time 22 minutes. The choice for a mode of commuting is strongly biased towards private means of transport (accounting for a 90.3 percent share). Table 1 reveals a strong dependence of commuting distance and time on the employed mode of transport. Most commutes by pedestrians or cyclists are short distances. Cars are used for somewhat longer distances (on average $21 \mathrm{~km}$ and 23 minutes). Public transport is - on average - used for longer distance commutes.

Table 1. Descriptive statistics, 2000-2008

\begin{tabular}{lrccc}
\hline Transport mode & \multicolumn{2}{c}{ Commuters } & Distance & Time \\
& observations & $\%$-share & $\mathrm{km}$ & $\mathrm{min}$ \\
Pedestrian & 3,561 & 2.3 & 1.0 & 8.1 \\
Bicycle & 41,023 & 26.6 & 4.4 & 12.5 \\
Motorbikes or scooter & 3,741 & 2.4 & 13.0 & 17.4 \\
Personal car & 90,925 & 59.0 & 21.2 & 23.4 \\
Private transport & 139,250 & 90.3 & 15.5 & 19.6 \\
Bus, tram, underground & 6,300 & 4.1 & 16.0 & 36.8 \\
Train & 8,688 & 5.6 & 41.1 & 54.6 \\
Public transport & 14,988 & 9.7 & 30.5 & 47.1 \\
Total & 154,238 & 100.0 & 17.0 & 22.3 \\
\hline
\end{tabular}

Note: Travel distance and time correspond to one-way trips.

Compared to other motorized means of transport, buses, trams, and the underground are relatively slow, taking an average time of $37 \mathrm{~min}$ for a $16 \mathrm{~km}$ average trip. Trains are used for particularly long commutes, with an average distance of $41.1 \mathrm{~km}$ and a commuting time of 55 min. The figures from Table 1 are consistent with what is generally found in the literature (see, for example OECD, 2010). Compared to other countries, commuting times are relatively long in the Netherlands. According to international comparative research Dutch workers spend an average of 51 minutes $^{4}$ on commuting per day in 2005 (the longest commuting time

\footnotetext{
${ }^{4}$ If we take into account that our figures refer to single trips per job, while part of the working population have multiple jobs, this figure is very similar to what we find.
} 
in their sample of 31 European countries), compared to 42 minutes in the EU-27 (ParentThirion et al., 2007; OECD, 2010).

The interdependence between the commuting distance, commuting time, and private versus public mode of transport is presented in Table 2. Whereas only 2.6 percent of all commutes by private means of transport take more than one hour, this figure is almost one fifth for public transport. A major share of 81.9 percent of commutes by private transport takes 30 minutes or less, whereas this figure is only 33.5 percent for public means of transport. The most likely explanations for this observation are that public transport is less efficient over shorter distances, possibly because of the distance between location of residence and the nearest bus stop or railway station, and that public means of transport are used more often in densely populated areas that are more congested and are characterized by generally lower speed. At the same time, commuting by foot or bicycle is suitable only for short distances.

Table 2. Commuters and distance by commuting time, 2000-2008

\begin{tabular}{lrccc}
\hline Time & \multicolumn{2}{c}{ Private transport } & \multicolumn{2}{c}{ Public transport } \\
Min & \%-share & distance $(\mathrm{km})$ & \%-share & distance $(\mathrm{km})$ \\
$0-15$ & 66.0 & 7.1 & 14.1 & 9.9 \\
$16-30$ & 15.9 & 19.8 & 19.4 & 15.6 \\
$31-60$ & 15.4 & 37.0 & 47.0 & 29.2 \\
$>60$ & 2.6 & 72.2 & 19.5 & 64.3 \\
\hline
\end{tabular}

Note: Travel distance and time correspond to one-way trips.

The average distance of a single trip is relatively stable over time, and ranges from $16 \mathrm{~km}$ in 2000 to $17.7 \mathrm{~km}$ in 2007. Commuting time ranges from 21.5 minutes to 23.3 minutes (in 2000 and 2007, respectively). Even though commuters live about as far from their work in 2000 than in 2008, there are some shifts in the use of different modes of transport. In particular, commutes by bike have become less popular over time (from a 29.0 percent share in 2000 to a 24.9 percent share in 2008), while the share of car users increased somewhat. In 2000, the car was used for 56.7 percent of commutes; in 2008 this figure was 61.2 percent. However, it is important to note that most changes occurred between 2005 and 2006 such that it cannot be ruled out that the observed trends are the result of a data revision. 


\section{Commuting behavior and education in Dutch agglomerations}

Figure 1 shows commuter flows of higher educated commuters (left) and lower educated commuters (right) between municipalities that represent 1,000 or more commuters. The largest commuter flows are within agglomerations, between the central municipalities and their surrounding suburban municipalities, as well as between peripheral municipalities. Although small in relative size, there are also substantial commuter flows between the largest agglomerations. Even though the Randstad ${ }^{5}$ is sometimes considered as a unique polycentric urban region, commuting patterns indicate that the agglomerations in this region are best seen as separate local labor markets, albeit with strong connections between some agglomerations in the area and with some overlapping boundaries.

Commuting patterns are not only asymmetric in direction (e.g., with a much higher inflow than outflow of commuters or vice versa); there is a strong interdependence between agglomeration and the level of education as well. The shades in Figure 1 represent the balance index of highly educated commuters (defined as the net inflow of highly educated commuters divided by the sum of the inflow and outflow) towards each agglomeration (which we refer to as in-commuters). Because of sample size, we have pooled all municipalities by agglomeration, and by NUTS-3 region in the periphery. In most agglomerations, the inflow of highly educated workers is larger than the outflow.

\footnotetext{
${ }^{5}$ The Randstad refers to the area in the Netherlands where the four largest agglomerations - Amsterdam, Rotterdam, The Hague and Utrecht - are located.
} 
Figure 1. Commuters and balance index of higher educated (left) and lower educated (right) commuters, 2008

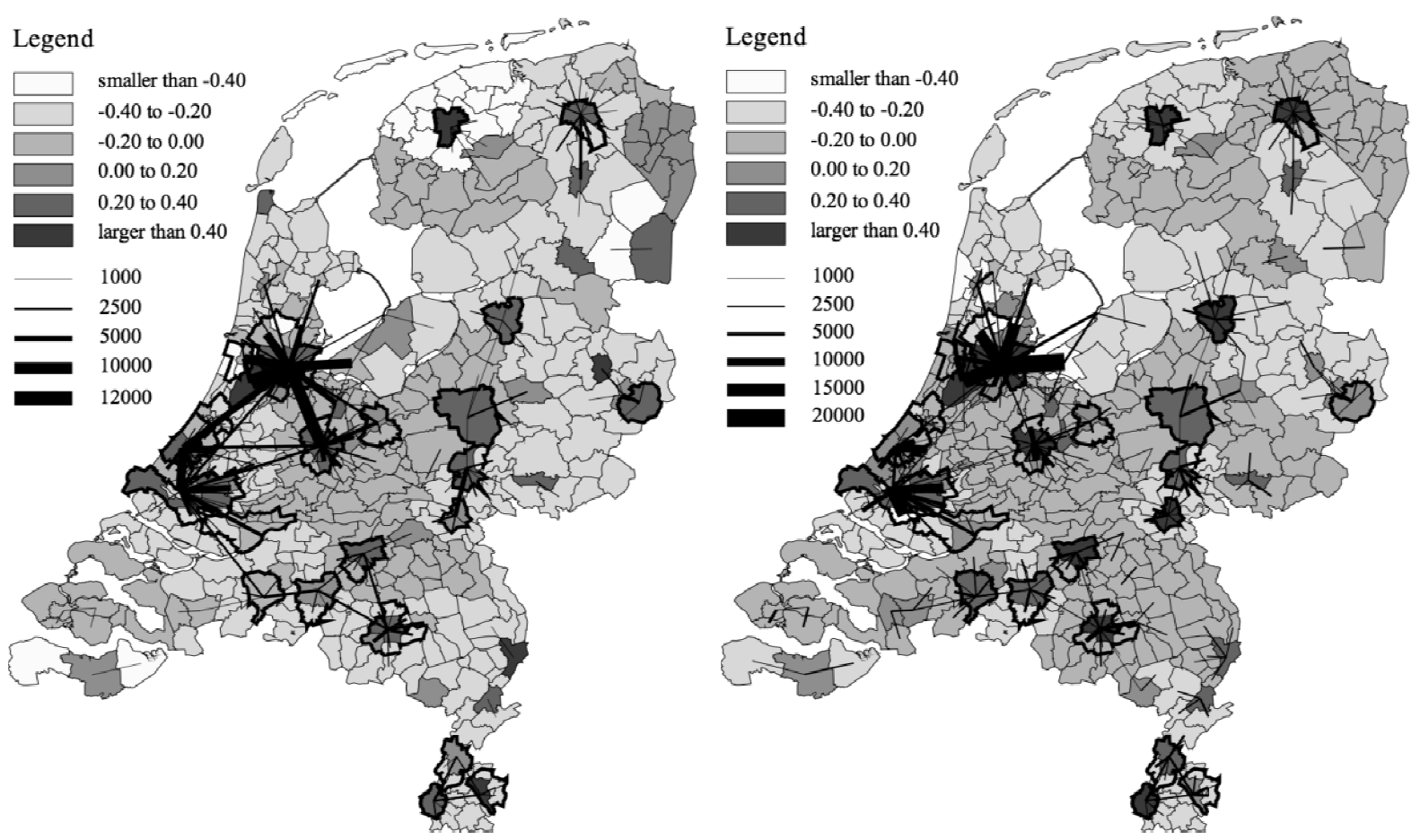

Notes: Balance index is defined as (inflow of commuters - outflow) / (inflow + outflow). Higher educated workers are those with at least higher tertiary education, lower educated workers are defined as all other workers. Stroked areas represent the 22 agglomerations defined by Statistics Netherlands.

Table 3 shows the share of private versus public transport by level of education, as well as the average commuting distance and time. While workers with only primary education commute just over $10 \mathrm{~km}$ on average, this figure is about twice as high for workers with a University (Master) degree. Higher educated workers are also more likely to use public transport. Workers with the lowest education levels, however, are somewhat more likely to use public transport than those with average education. This may be related to budget constraints, as lower educated are disproportionately likely to use public transport for short-distance commutes. 
Table 3. Commuting distance and time by type of education, 2000-2008

\begin{tabular}{|c|c|c|c|c|c|c|}
\hline \multirow[t]{2}{*}{ Type of education } & \multicolumn{3}{|c|}{ Private transport } & \multicolumn{3}{|c|}{ Public transport } \\
\hline & $\%$-share & $\begin{array}{c}\text { distance } \\
\mathrm{km}\end{array}$ & $\begin{array}{l}\text { time } \\
\text { min }\end{array}$ & $\%$-share & $\begin{array}{c}\text { distance } \\
\mathrm{km}\end{array}$ & $\begin{array}{r}\text { time } \\
\text { min }\end{array}$ \\
\hline Primary education & 92.0 & 10.5 & 15.5 & 8.0 & 15.7 & 38.0 \\
\hline Lower secondary education (VMBO, MBO 1) & 92.7 & 12.3 & 16.6 & 7.3 & 21.6 & 41.1 \\
\hline Higher secondary education (HAVO, VWO) & 97.2 & 15.3 & 20.4 & 12.8 & 27.0 & 45.2 \\
\hline Lower tertiary education (MBO 2, 3) & 93.0 & 13.5 & 17.2 & 7.0 & 24.3 & 41.8 \\
\hline Lower tertiary education (MBO 4) & 93.7 & 15.5 & 19.2 & 6.3 & 28.6 & 45.4 \\
\hline Higher tertiary education ( $\mathrm{HBO}, \mathrm{BA})$ & 91.3 & 17.5 & 21.8 & 8.7 & 33.4 & 49.5 \\
\hline Higher tertiary education (MA, $\mathrm{PhD})$ & 82.6 & 20.0 & 24.9 & 17.4 & 41.1 & 54.3 \\
\hline
\end{tabular}

Note: Travel distance and time correspond to one-way trips

\section{Econometric analyses}

The attractiveness of locations as a place of residence (due to amenities) and the attractiveness of locations as a place to work (due to higher productivity and wages) are two major driving forces behind commuting patterns. As a location becomes, ceteris paribus, more attractive as a place of residence, land rents will go up and the net-inflow of workers will decrease. If a location becomes more attractive to work, land rents will go up as well, but (because of the trade-off between migrating and commuting) the net-inflow of workers will go up. Interestingly, theory predicts that the actual outcomes in terms of commuter flows may differ substantially between low and highly educated workers.

If we assume that higher educated workers can pay more for better residential locations compared to lower educated workers, it is to be expected that better locations to live have a relatively low net-inflow of highly educated compared to the inflow of lower educated workers because of spatial sorting. The effect of productivity is likely to be asymmetric to the level of education as well, but in opposite direction. Agglomeration economies are generally thought to be larger for higher educated workers (explaining the high concentration of jobs for higher educated workers in cities). Therefore, productivity effects are likely to increase the net-inflow of higher educated workers stronger than the net-inflow of lower educated workers.

\section{Direction of flows}

Table 4 presents the share of highly educated workers in the flow of in-commuters towards each of the 22 Dutch agglomerations, the flow of out-commuters, and the flows within the 
same municipality. Furthermore, it shows balance indexes for both higher and lower educated commuters, and land rents. The average share of highly educated commuters (e.g., with at least higher tertiary education) is 38 percent for workers who live and work in the agglomeration, 44 percent in the flow of commuters towards the agglomerations, and 47 percent in the outflow. Higher educated workers are thus far more likely to commute than lower educated, regardless of the direction.

We find that commuters that live in an agglomeration but work somewhere else are relatively highly educated. This is clearly consistent with the prediction that higher educated workers are more likely to find a better paid job further away than lower educated. Even though the finding that the flow of out-commuters from the largest agglomerations consists of such a high share of highly educated workers is puzzling at first sight, it is in fact rather intuitive. As lower educated workers living in the larger agglomerations are very likely to work close by - they have little incentive to commute due to relatively high costs of commuting relative to their wage and because of a less complex job match - the remaining out-commuters from the large cities are highly educated workers. This is particularly the case for agglomerations that are far away from other agglomerations, like Groningen.

Even though most agglomerations have a substantial net-inflow of higher educated workers, there are a few notable exceptions to this. Haarlem and Leiden, which have the lowest balance indexes for highly skilled commuters in the Randstad, are amongst the top four agglomerations with the highest land rents. Both Haarlem and Leiden are known as particularly attractive residential locations. Also interesting are the stylized facts for the four largest Dutch agglomerations. Amsterdam and Utrecht are generally considered to be cities where people want to live because they are attractive in terms of amenities, while people go to Rotterdam and The Hague for work. Not coincidental (as further analyses later in this paper will show), Amsterdam and Utrecht have a relatively high share of highly educated workers that both live and work locally, while out-commuters are higher educated than incommuters. For Rotterdam and The Hague these figures are the exact opposite. The same holds for the balance indexes: Amsterdam and Utrecht attract relatively many lower educated commuters, while Rotterdam and The Hague attract higher educated commuters that prefer to live elsewhere. 
Table 4. Share of highly educated workers by type of commuter, 2000-2008

\begin{tabular}{|c|c|c|c|c|c|c|}
\hline \multirow[t]{2}{*}{ Agglomeration } & \multicolumn{3}{|c|}{ Share of higher tertiary educated (percent) } & \multicolumn{2}{|c|}{ Balance index } & \multirow{2}{*}{$\begin{array}{l}\text { Land rent } \\
\text { Euro/m² }\end{array}$} \\
\hline & $\begin{array}{c}\text { in- } \\
\text { commuters }\end{array}$ & $\begin{array}{l}\text { out- } \\
\text { commuters }\end{array}$ & $\begin{array}{l}\text { Within } \\
\text { municipality }\end{array}$ & $\begin{array}{c}\text { higher } \\
\text { educated }\end{array}$ & $\begin{array}{c}\text { lower } \\
\text { educated }\end{array}$ & \\
\hline Amsterdam & 47.0 & 49.7 & 44.8 & 0.386 & 0.431 & 582 \\
\hline The Hague & 53.8 & 47.4 & 40.3 & 0.337 & 0.218 & 568 \\
\hline Haarlem & 41.2 & 51.7 & 34.7 & -0.263 & -0.055 & 542 \\
\hline Leiden & 45.9 & 52.3 & 40.4 & -0.155 & -0.027 & 478 \\
\hline Utrecht & 48.9 & 56.1 & 45.7 & 0.187 & 0.321 & 389 \\
\hline Rotterdam & 39.6 & 35.8 & 30.6 & 0.237 & 0.160 & 292 \\
\hline 's-Hertogenbosch & 45.2 & 56.3 & 34.0 & 0.282 & 0.473 & 277 \\
\hline Amersfoort & 46.2 & 51.7 & 32.4 & -0.093 & 0.016 & 259 \\
\hline Maastricht & 46.0 & 52.8 & 41.1 & 0.400 & 0.508 & 242 \\
\hline Zwolle & 38.3 & 51.5 & 38.5 & 0.359 & 0.567 & 234 \\
\hline Eindhoven & 46.2 & 48.8 & 41.9 & 0.260 & 0.307 & 233 \\
\hline Groningen & 43.7 & 64.4 & 49.2 & 0.312 & 0.633 & 225 \\
\hline Breda & 40.9 & 59.0 & 36.3 & 0.021 & 0.370 & 225 \\
\hline Dordrecht & 32.2 & 33.6 & 28.3 & -0.126 & -0.095 & 217 \\
\hline Tilburg & 43.2 & 49.2 & 32.7 & 0.048 & 0.168 & 213 \\
\hline Leeuwarden & 40.5 & 47.0 & 35.6 & 0.586 & 0.667 & 197 \\
\hline Nijmegen & 45.0 & 68.5 & 50.8 & 0.142 & 0.560 & 192 \\
\hline Arnhem & 43.6 & 50.8 & 38.6 & 0.420 & 0.531 & 187 \\
\hline Periphery & 35.3 & 36.5 & 26.2 & -0.181 & -0.157 & 143 \\
\hline Enschede & 44.1 & 39.1 & 31.6 & 0.388 & 0.297 & 118 \\
\hline Geleen/Sittard & 31.8 & 38.6 & 32.2 & -0.031 & 0.119 & 110 \\
\hline Apeldoorn & 40.6 & 43.0 & 29.7 & 0.269 & 0.313 & 103 \\
\hline Heerlen & 37.4 & 28.5 & 25.5 & 0.214 & 0.015 & 89 \\
\hline
\end{tabular}

Notes: Persons who live and work in the same municipality. The periphery is defined as all municipalities outside the 22 agglomerations defined by Statistics Netherlands. For the periphery, this can be either from another peripheral municipality or from a municipality in one of the agglomerations, but not from the same municipality. Balance index is defined as (inflow of commuters - outflow) / (inflow + outflow).

Figure 2 presents two scatter diagrams that show the relation between land rents and the balance index for higher educated workers (left panel) and lower educated workers (right panel). Generally, municipalities with higher land rents have a higher balance index, which implies that there are relatively more incoming than outgoing commuters. As the size of the data points indicate, however, this is mostly explained by the fact that larger municipalities have both relatively high land rents and more commuters arriving from the surrounding area. 
Figure 2. Land rents and balance index of higher educated (left) and lower educated (right) commuters by municipality, 2008
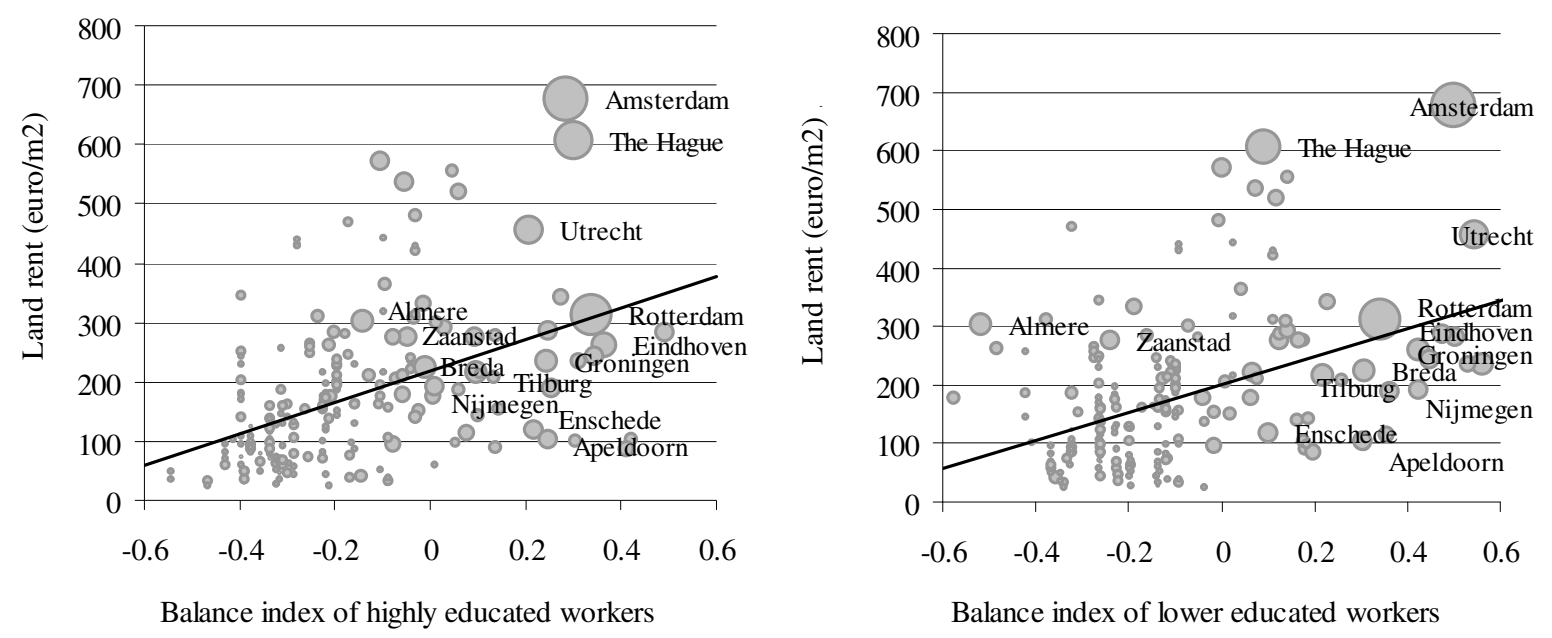

Notes: Balance index is defined as (inflow of commuters - outflow) / (inflow + outflow). Higher educated workers are those with at least higher tertiary education, lower educated workers are defined as all other workers. The size of the data points represents population.

To disentangle the effects of productivity and amenities, we have estimated two (OLS) regressions that explain the direction of commuter flows (as measured by the balance index) for 445 Dutch municipalities; one for lower educated workers, and one for higher educated workers. To control for agglomeration, we have included (the natural logarithm of) population and density. As an indicator for productivity, we have included the wage premiums that were estimated by Groot et al. (2011). ${ }^{6}$ As an indicator for land rents, we have included the estimates of De Groot (2011). We thus estimate the following equation:

$$
\text { Balance }_{i}=\alpha+\beta_{1} \log (\text { population })_{i}+\beta_{2} \log \left(\text { density }_{i}+\beta_{3} \text { wage }_{i}+\beta_{4} \log (\text { land rent })_{i}+\varepsilon_{i}\right.
$$

It is important to note that our methodology considers labor supply as exogenous. In reality, however, it is well possible that a worker considers commuting distance and supply of labor simultaneously. Even though we do not account for this, empirical evidence shows that the effect of distance on the supply of labor (both in terms of total labor supply and number of working days per week) is rather weak (Gutiérrez-i-Puigarnau and Van Ommeren, 2010). Therefore, endogeneity of labor supply is unlikely to result in biased estimation results.

\footnotetext{
${ }^{6}$ These are obtained by estimating a Mincerian wage regression, and represent the regional component of the part of individual wages that is not explained by observed human capital (see Groot et al., 2011).
} 
The estimation results are presented in Table 5. As predicted, agglomeration has a stronger effect on commuting of higher educated workers relative to lower educated workers. Doubling population at a given area (such that both population and density double), is expected to result in a 26 percent increase in the net-inflow of higher educated workers while this figure is only 13 percent for lower educated workers. Furthermore, the symmetry of the flow of lower educated workers is insensitive to the wage premium, while it is positive and significant for the flow of higher educated workers. The effect of land rents on the net-inflow of commuters is negative and significant for higher educated workers, and positive and significant for lower educated workers. Even though the regressions may be somewhat vulnerable to multicollinearity (because the independents are correlated), regressions with additional control variables that were estimated as a robustness check yield similar results as those presented below.

Table 5. Regression results, direction of commuter flows

\begin{tabular}{lccc}
\hline $\begin{array}{l}\text { Dependent variable: } \\
\text { balance index }\end{array}$ & $\begin{array}{c}\text { Lower educated } \\
\text { workers }\end{array}$ & $\begin{array}{c}\text { Higher educated } \\
\text { workers }\end{array}$ & All workers \\
\# Observations & 437 & 437 & 437 \\
Log population & $0.147^{* * *}$ & $0.199^{* * *}$ & $0.165^{* * *}$ \\
Log population density & $(7.0)$ & $(11.1)$ & $(10.1)$ \\
& -0.015 & $0.060^{* *}$ & 0.015 \\
Wage residual & $(0.8)$ & $(3.1)$ & $(0.8)$ \\
& 0.096 & $0.596^{*}$ & 0.451 \\
Land rent & $(0.3)$ & $(2.2)$ & $(1.9)$ \\
& $0.090^{* * *}$ & $-0.094^{* * *}$ & 0.012 \\
$R^{2}$ & $(3.4)$ & $(3.7)$ & $(0.5)$ \\
\hline
\end{tabular}

Notes: $t$-values (in absolute values) are in parentheses. Significance levels of 0.05, 0.01 and 0.001 are denoted by ${ }^{*},{ }^{* *}$ and ${ }^{* * *}$ respectively.

\section{Explanation of commuting distance and time}

In the previous sections, several stylized facts on commuter distance and time were presented. We have seen that higher educated commuters travel longer distances on average, while commutes towards the larger agglomerations tend to have a longer commuting time on average as well. Furthermore, the previous section has presented the results of regression analyses on the meso (municipality) level to gain insight in asymmetries in the direction of commuter flows that are related to education. We now revert to micro level analyses, to explain commuting behavior of individual employees. 
This section uses OLS regressions to estimate the impact on distance and time travelled of personal characteristics of commuters and of characteristics of the municipality of destination. To account for the latter, we include employment density of the destination municipality and the population density and ratio between job and population of the residence municipality. Because the latter variable is endogenous - as a lower ratio between job and population automatically implies that more residents have to commute - we estimate our regression equation both including and excluding this variable. Dependent variables are the natural logarithm of distance (of a one-way commute) and time. We thus estimate four similar regression equations:

$$
\begin{aligned}
& \log \left(\text { dist }_{i}\right)=\alpha+\sum_{\text {edu }=1}^{8} \beta_{1, \text { edu }} D_{\text {edu }}+\beta_{2, \text { age }} D_{\text {age }}+\beta_{3} D_{\text {female }}+\beta_{4} D_{\text {part-time }}+\beta_{5} D_{\text {married }} \\
& +\beta_{6} \log \left(w_{i}\right)+\sum_{\text {ind }=1}^{4} \beta_{7, \text { ind }} D_{\text {ind }}+\beta_{8} \log \left(\text { emp. density }{ }_{i}\right)+\beta_{9} \log (\text { pop. density }) \\
& +\beta_{10} \text { ratio }_{i}+\beta_{11} \log \left(\text { wage premium }_{i}\right)+\beta_{12} \log \left(\text { land rent }_{i}\right)+\sum_{\text {year }=1}^{9} \beta_{13, \text { year }} D_{\text {year }}+\varepsilon_{i} \cdot
\end{aligned}
$$

To account for both the quantity and the quality of education, we include a set of dummies for each level of education. Additional dummies are included for 5-year age groups (to account for nonlinearities in the effect of age), female gender, part-time work, whether a commuter is married or not, and the industry of employment. As an additional control variable we include the $\log$ of the hourly wage. It is, for example, well possible that differences in commuter behavior of workers with different levels of education that were observed in the previous section are in fact due to wage differences (where high paid workers have a stronger incentive to commute). Hence, by controlling for the wage, education variables can take into account the system of preferences that can be shaped by education.

While there is no strong relationship between commuting distance and wages (Manning, 2003; Gutiérrez-i-Puigarnau and Van Ommeren, 2010), wages are often thought to be endogenous with respect to commuting time. Workers with a higher wage are likely to travel faster because they have a higher opportunity cost of time. We must therefore be careful not draw any conclusions from the estimated wage effect but rather include the individual wage as a control. The $\log$ of the density of the municipality where each employee works is calculated by dividing total employment in this municipality by area. The ratio between jobs and population is calculated by dividing total employment in the municipality where a worker 
lives by the total working population. Because of the trade-off between commuting time and wage, we include the regional wage residual (at the work location) that was introduced earlier in this section. Also, we include land rents at the residence location. As we use pooled data, we include year dummies to account for year specific effects.

The results of the estimated models are presented in Table 6. Males commute further distances than females. Older workers make shorter commutes and part-time workers somewhat shorter commutes as well. Somewhat unexpectedly, given the literature that was discussed earlier, the (log) hourly wage has a rather strong effect on commuting distance. Workers with higher wages commute further. The effect of individual wages on commuting time is much weaker, about half of the effect on distance. Taking into account that most explanatory variables have a similar effect on commuting time and distance, a straightforward interpretation of this difference would be that workers with higher wages indeed travel faster. Even when hourly wages are included, however, the level of education has a strong effect of its own.

The higher the level of education, the longer the distance from home to work and the time needed to travel. Whether a worker is married or not has almost no effect on commuting. This is consistent with the finding of Rouwendal and Van der Straaten (2004) that dual earners do not have a higher commuting time compared to single earners, because they have a relatively high willingness to pay for housing close to large labor markets. For almost all variables, the effects of the independents on commuting distance are similar to that on commuting time. The employment density of the job location is, however, an exception to this. Workers who travel to more densely populated municipalities commute considerably further in terms of commuting time, but only slightly further in terms of distance. A one percent higher economic density results in a 0.16 percent longer commuting time. The effect of population density in the residence municipality on commuting distance is opposite: workers who live in densely populated areas commute over shorter distance. Congestion provides a possible explanation for the differences in the effect on commuting distance versus travel time. It is, however, also possible that workers who commute to or from more densely populated municipalities are more likely to use less efficient modes of transport (like bicycles or public transport instead of cars).

Workers who commute towards municipalities that offer relatively higher wages (after correcting for worker characteristics, as measured by the wage residual) have on average a far larger commuting distance and time. This effect is economically very significant: a one percent increase in the non-competitive wage component is associated with a 4.2 (4.8) 
percent longer commuting distance (time). At the same time, workers who live in municipalities where land rents are low tend to live further from their work. This is consistent with the view that there is a trade-off between commuting time (and thus costs including opportunity costs of time) and residential location choice.

There is no strong relationship between commuter distance and time and the industry in which a worker is employed, although workers in private services commute somewhat further and those in agriculture somewhat less. Including industry dummies at the 2-digit NACE rev. 1.1 level, as a robustness check, did not have a substantial effect on the key variables in our regression model. Trends in the year dummies that were included in all regressions indicate changes over time in commuting behavior after correcting for composition effects. Across all estimated models, however, there is almost no year specific trend in travel distance and time.

It is well possible that the effect of income on commuting distance and time depends on the level of education of workers. For example, it is well possible that, even at a given level of income, higher educated are more often able to work while commuting. This would explain their higher use of the train as a mode of transport (as a train is more suitable as a working environment compared to other modes of transport). To account for this possibility, we have included interaction effects between wages and education in our regression models. ${ }^{7}$ Figure 3 graphically displays the estimation results of a model that is similar to model (I) in Table 6 on all accounts other than the inclusion of wage-education interaction effects. Independent of income, higher educated workers travel further. The effect of wage on travel distance, however, is particularly high for lower educated workers while it almost disappears for university graduates.

\footnotetext{
${ }^{7}$ As a robustness check, we have also estimated models that include interaction effects between education and other variables. These, however, did not show strong interaction effects.
} 


\begin{tabular}{|c|c|c|c|c|}
\hline \multirow[t]{2}{*}{ Dependent variable: } & \multicolumn{2}{|c|}{ Log distance } & \multicolumn{2}{|c|}{ Log time } \\
\hline & (I) & (II) & (III) & (IV) \\
\hline \# Observations & 118,757 & 67,606 & 146,759 & 83,343 \\
\hline Female & $\begin{array}{l}-0.147^{* * *} \\
(24.4)\end{array}$ & $\begin{array}{l}-0.146^{* * *} \\
(17.6)\end{array}$ & $\begin{array}{l}-0.143^{* * *} \\
(25.1)\end{array}$ & $\begin{array}{l}-0.143^{* * *} \\
(18.2)\end{array}$ \\
\hline Part-time worker & $\begin{array}{l}-0.074^{* * *} \\
(12.7)\end{array}$ & $\begin{array}{l}-0.083^{* * *} \\
(10.2)\end{array}$ & $\begin{array}{l}-0.066^{* * *} \\
(12.1)\end{array}$ & $\begin{array}{l}-0.081^{* * *} \\
(10.5)\end{array}$ \\
\hline Log hourly wage & $\begin{array}{l}0.287^{* * *} \\
(34.7)\end{array}$ & $\begin{array}{l}0.269^{* * *} \\
(23.3)\end{array}$ & $\begin{array}{l}0.161^{* * *} \\
(20.6)\end{array}$ & $\begin{array}{l}0.154^{* * *} \\
(14.1)\end{array}$ \\
\hline Married & $\begin{array}{l}-0.039^{* * *} \\
(7.0)\end{array}$ & $\begin{array}{l}-0.050^{* * *} \\
(6.8)\end{array}$ & $\begin{array}{l}-0.023^{* * *} \\
(4.3)\end{array}$ & $\begin{array}{l}-0.033^{* * *} \\
(4.7)\end{array}$ \\
\hline Manufacturing* & $\begin{array}{l}0.145^{* * *} \\
(4.3)\end{array}$ & $\begin{array}{l}-0.073 \\
(1.1)\end{array}$ & $\begin{array}{l}0.180^{* * *} \\
(5.7)\end{array}$ & $\begin{array}{l}-0.003 \\
(0.1)\end{array}$ \\
\hline Private services & $\begin{array}{l}0.275^{* * *} \\
(8.2)\end{array}$ & $\begin{array}{l}0.097 \\
(1.4)\end{array}$ & $\begin{array}{l}0.235^{* * *} \\
(7.5)\end{array}$ & $\begin{array}{l}0.085 \\
(1.3)\end{array}$ \\
\hline Public services & $\begin{array}{l}0.147^{* * *} \\
(4.4)\end{array}$ & $\begin{array}{l}-0.059 \\
(0.9)\end{array}$ & $\begin{array}{l}0.144^{* * *} \\
(4.6)\end{array}$ & $\begin{array}{l}-0.037 \\
(0.6)\end{array}$ \\
\hline $\begin{array}{l}\text { Log employment density } \\
\text { (job location) }\end{array}$ & $\begin{array}{l}0.040^{* * *} \\
(14.5)\end{array}$ & $\begin{array}{l}0.042^{* * *} \\
(11.3)\end{array}$ & $\begin{array}{l}0.163^{* * *} \\
(60.0)\end{array}$ & $\begin{array}{l}0.167^{* * *} \\
(45.9)\end{array}$ \\
\hline $\begin{array}{l}\text { Log population density } \\
\text { (residence location) }\end{array}$ & $\begin{array}{l}-0.087^{* * *} \\
(21.6)\end{array}$ & $\begin{array}{l}-0.078^{* * *} \\
(14.4)\end{array}$ & $\begin{array}{l}-0.060^{* * *} \\
(15.6)\end{array}$ & $\begin{array}{l}-0.061^{* * *} \\
(11.6)\end{array}$ \\
\hline $\begin{array}{l}\text { Ratio jobs to population } \\
\text { (residence location) }\end{array}$ & & $\begin{array}{l}-0.201^{* * *} \\
(17.9)\end{array}$ & & $\begin{array}{l}-0.157^{* * *} \\
(14.8)\end{array}$ \\
\hline $\begin{array}{l}\text { Wage residual } \\
\text { (job location) }\end{array}$ & $\begin{array}{l}4.227^{* * *} \\
(63.1)\end{array}$ & $\begin{array}{l}4.562^{* * *} \\
(51.2)\end{array}$ & $\begin{array}{l}4.856^{* * *} \\
(76.7)\end{array}$ & $\begin{array}{l}5.166^{* * *} \\
(61.5)\end{array}$ \\
\hline $\begin{array}{l}\text { Land rent } \\
\text { (residence location) }\end{array}$ & $\begin{array}{l}-0.193^{* * *} \\
(29.8)\end{array}$ & $\begin{array}{l}-0.181^{* * *} \\
(21.0)\end{array}$ & $\begin{array}{l}-0.140^{* * *} \\
(22.8)\end{array}$ & $\begin{array}{l}-0.129^{* * *} \\
(15.9)\end{array}$ \\
\hline $\begin{array}{l}\text { Lower secondary education } \\
(\mathrm{VMBO}, \mathrm{MBO} 1)\end{array}$ & $\begin{array}{l}0.035^{*} \\
(2.4)\end{array}$ & $\begin{array}{l}0.056^{* *} \\
(2.9)\end{array}$ & $\begin{array}{l}-0.007 \\
(0.5)\end{array}$ & $\begin{array}{l}0.014 \\
(0.8)\end{array}$ \\
\hline $\begin{array}{l}\text { Lower tertiary education } \\
(\mathrm{MBO} 2,3)\end{array}$ & $\begin{array}{l}0.113^{* * *} \\
(8.1)\end{array}$ & $\begin{array}{l}0.139^{* * *} \\
(7.6)\end{array}$ & $\begin{array}{l}0.063^{* * *} \\
(5.0)\end{array}$ & $\begin{array}{l}0.094^{* * *} \\
(5.7)\end{array}$ \\
\hline $\begin{array}{l}\text { Lower tertiary education } \\
(\mathrm{MBO} 4)\end{array}$ & $\begin{array}{l}0.185^{* * *} \\
(13.5)\end{array}$ & $\begin{array}{l}0.206^{* * *} \\
(11.3)\end{array}$ & $\begin{array}{l}0.165^{* * *} \\
(13.3)\end{array}$ & $\begin{array}{l}0.193^{* * *} \\
(11.8)\end{array}$ \\
\hline $\begin{array}{l}\text { Higher secondary education } \\
\text { (HAVO, VWO) }\end{array}$ & $\begin{array}{l}0.200^{* * *} \\
(13.0)\end{array}$ & $\begin{array}{l}0.215^{\text {*** }} \\
(10.7)\end{array}$ & $\begin{array}{l}0.204^{* * *} \\
(14.7)\end{array}$ & $\begin{array}{l}0.220^{* * *} \\
(12.1)\end{array}$ \\
\hline $\begin{array}{l}\text { Higher tertiary education } \\
(\mathrm{HBO}, \mathrm{BA})\end{array}$ & $\begin{array}{l}0.287^{* * *} \\
(20.4)\end{array}$ & $\begin{array}{l}0.303^{* * *} \\
(16.5)\end{array}$ & $\begin{array}{l}0.274^{* * * *} \\
(21.6)\end{array}$ & $\begin{array}{l}0.282^{* * *} \\
(17.1)\end{array}$ \\
\hline $\begin{array}{l}\text { Higher tertiary education } \\
(\mathrm{MA}, \mathrm{PhD})\end{array}$ & $\begin{array}{l}0.379^{* * *} \\
(24.7)\end{array}$ & $\begin{array}{l}0.411^{* * *} \\
(20.3)\end{array}$ & $\begin{array}{l}0.387^{* * *} \\
(27.6)\end{array}$ & $\begin{array}{l}0.416^{* * *} \\
(22.6)\end{array}$ \\
\hline Year dummies & Yes & Yes & Yes & Yes \\
\hline Age dummies (5-year groups) & Yes & Yes & Yes & Yes \\
\hline$R^{2}$ & 0.135 & 0.154 & 0.145 & 0.161 \\
\hline
\end{tabular}

Notes: $t$-values (in absolute values) are in parentheses. Omitted industry is agriculture; omitted education category is primary education. Significance levels of $0.05,0.01$ and 0.001 are denoted by $^{*},{ }^{* *}$ and ${ }^{* * *}$. In model (1), the regression coefficients by age group are as follows: -0.02 (for the group 20-25), 0.01 (for 25-30), 0.00 (for 30-35), -0.06 (for 35-40), -0.11 (for 40-45), -0.16 (for $45-50$ ), -0.18 (for 50-55), -0.21 (for 55-60) and -0.24 (for 60-65). As the estimated effect of age is comparable across models, we do not report our estimations for all models. 
Figure 3. Education dummies (left) and interaction of education and log wage (right)

Dependent variable: log commuting distance
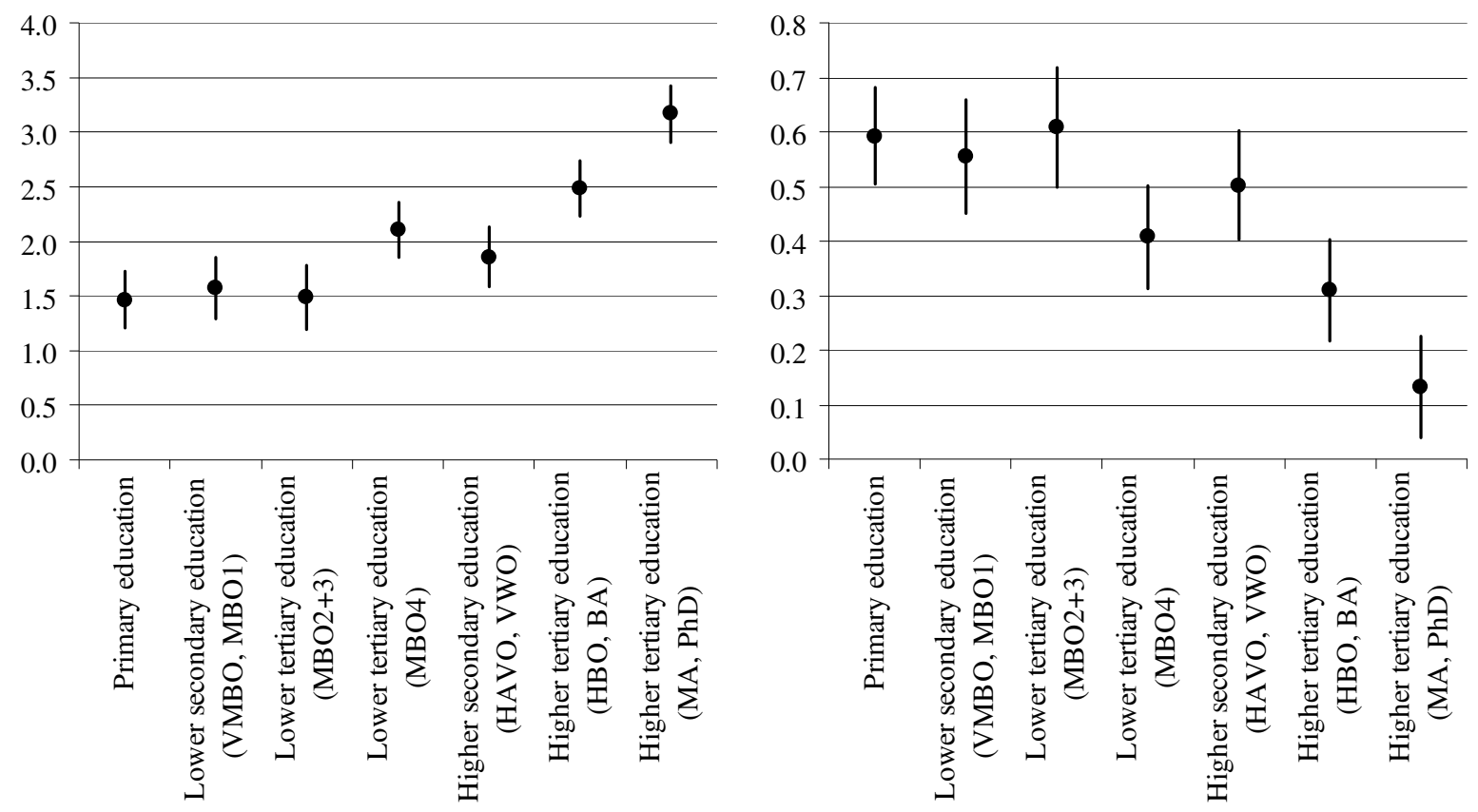

Note: bars correspond to $95 \%$ confidence intervals for the estimated coefficients. Estimates are obtained by adding interaction effects to regression (I) in Table 6 and removing log wage and the constant term.

As discussed in previous sections of this paper, there is a strong interdependency between regional productivity on the one hand, and the structure of the work force on the other (see also, for example, Combes et al., 2008 and Groot et al., 2011). Even though we include several control variables to account for regional characteristics (in particular for the attractiveness of regions), we cannot rule out the possibility that spatial sorting of workers resulting in a correlation between level of education and other worker characteristics - has resulted in biased estimates due to multicollinearity. To check whether the relation between education and commuting still holds independently of residence and work municipality, we re-estimate equation (2) with fixed effects for residence municipality and work municipality, thus controlling for all region specific effects. Estimation results are shown in Table 7. Including fixed effects does not result in any notable change in parameter estimates. The results once more indicate that higher educated workers commute substantially further than lower educated workers, both in terms of distance and time. Also, the effects of level of education on commuting distance and time are again quantitatively similar, which indicates that higher educated workers do not commute faster. 
Table 7. Regression results with region fixed effects, 2000-2008

\begin{tabular}{|c|c|c|}
\hline Dependent variable: & Log distance & Log time \\
\hline \# Observations & 118,757 & 146,759 \\
\hline \multirow[t]{2}{*}{ Female } & $-0.129^{* * *}$ & $-0.128^{* * *}$ \\
\hline & $(22.2)$ & $(23.1)$ \\
\hline \multirow[t]{2}{*}{ Part-time worker } & $-0.068^{* * *}$ & $-0.057^{* * *}$ \\
\hline & $(12.0)$ & $(10.7)$ \\
\hline \multirow[t]{2}{*}{ Log hourly wage } & $0.278^{* * *}$ & $0.148^{* * *}$ \\
\hline & $(34.9)$ & $(19.5)$ \\
\hline \multirow[t]{2}{*}{ Married } & $-0.040^{* * *}$ & $-0.016^{* *}$ \\
\hline & $(7.3)$ & $(3.1)$ \\
\hline \multirow[t]{2}{*}{ Manufacturing* } & $0.165^{* * *}$ & $0.190^{* * *}$ \\
\hline & $(5.0)$ & $(6.1)$ \\
\hline \multirow[t]{2}{*}{ Private services } & $0.256^{* * *}$ & $0.190^{* * *}$ \\
\hline & $(7.8)$ & $(6.2)$ \\
\hline \multirow[t]{2}{*}{ Public services } & $0.143^{* * *}$ & $0.112^{* * *}$ \\
\hline & $(4.3)$ & $(3.6)$ \\
\hline \multirow{2}{*}{$\begin{array}{l}\text { Lower secondary education } \\
(\mathrm{VMBO}, \mathrm{MBO} 1)\end{array}$} & 0.026 & -0.010 \\
\hline & $(1.9)$ & $(0.8)$ \\
\hline \multirow{2}{*}{$\begin{array}{l}\text { Lower tertiary education } \\
(\mathrm{MBO} 2,3)\end{array}$} & $0.096^{* * *}$ & $0.077^{* * *}$ \\
\hline & $(7.2)$ & $(5.4)$ \\
\hline \multirow{2}{*}{$\begin{array}{l}\text { Lower tertiary education } \\
(\mathrm{MBO} 4)\end{array}$} & $0.168^{* * *}$ & $0.144^{* * *}$ \\
\hline & $(12.6)$ & (11.9) \\
\hline \multirow{2}{*}{$\begin{array}{l}\text { Higher secondary education } \\
\text { (HAVO, VWO) }\end{array}$} & $0.178^{* * *}$ & $0.173^{* * *}$ \\
\hline & $(12.1)$ & $(12.8)$ \\
\hline \multirow{2}{*}{$\begin{array}{l}\text { Higher tertiary education } \\
(\mathrm{HBO}, \mathrm{BA})\end{array}$} & $0.270^{* * *}$ & $0.249^{* * *}$ \\
\hline & (19.9) & $(20.2)$ \\
\hline \multirow{2}{*}{$\begin{array}{l}\text { Higher tertiary education } \\
(\mathrm{MA}, \mathrm{PhD})\end{array}$} & $0.384^{* * *}$ & $0.364^{* * *}$ \\
\hline & $(25.8)$ & $(26.7)$ \\
\hline$R^{2}$ & 0.168 & 0.100 \\
\hline
\end{tabular}

Notes: $t$-values (in absolute values) are in parentheses. Omitted industry is agriculture; omitted education category is primary education. Specifications include fixed effects for year, age (5year groups), residence municipality and municipality of job location.

\section{Explanation of the choice of mode of transport}

In this section, we employ multivariate logit models to explain the use of five different modes of transport by a total of 139,127 commuters. ${ }^{8}$ Our basic specification is the same as equation (1) that was estimated in the previous section. Additionally, we include the commuting distance. We have calculated marginal effects for the pedestrians (column I), the use of bicycles (column II), personal cars (column III), bus, tram and underground (column IV) and the train (column V). The estimated marginal effects are reported in Table 8.

\footnotetext{
${ }^{8}$ For computational reasons we have chosen to use multinomial logit rather than multinomial probit. As a robustness check, we compared the two estimators on a 5\% subsample of our dataset. Both methods yield comparable results.
} 
The distance of commutes is the variable with the strongest explanatory power. Doubling the distance of a commute decreases the probability that the bicycle is used by 25 percent, while it increases the probability that a car is used by 22 percent. For all modes of transport, with the exception of trams, buses and the underground, distance has a very strong effect on the probability that each mode is used. Females are somewhat less likely to commute by bike, and more likely to commute by car or bus, tram or underground. There is no relation between age and mode of commuting, hence we do not report the estimated results for the nine age dummies that were included. Workers commuting to higher paid jobs are more likely to commute by car, and less likely to commute by bicycle.

As noted in the introduction, the higher use of public transport by higher educated individuals could be to some extent institutionalized because public sector employees (who are somewhat higher educated on average) often receive compensation for commuting expenses when they use public transport, but not when using personal cars. Our empirical results are, however, inconsistent with this hypothesis. There is no statistically significant difference between the effects of working in private services and working in public services on the probability that busses, trams, underground railways or trams are used. Public servants do, however, seem to use bicycles somewhat more often than workers in other sectors.

The results in Table 8 should be interpreted as the expected marginal effect of a change in the independents by ' 1 ' on the probability that a commuter uses each respective mode of transport. The level of education has almost no effect on the probability that an individual will walk from home to work. Higher educated workers are more likely to commute by bike or by train, but less likely to commute by personal car or bus, tram or underground. Having a university degree is associated to a ceteris paribus 26 percent higher probability to commute to work by bicycle compared to having only finished elementary school, while the probability to commute by personal car is 27 percent lower and the probability to use the train is 2.6 percent higher. 
Table 8. Regressions results: multinomial logit by mode of transport, 2000-2008

\begin{tabular}{|c|c|c|c|c|c|}
\hline $\begin{array}{l}\text { Marginal effects by } \\
\text { mode of transport }\end{array}$ & Pedestrian & Bicycle & $\begin{array}{l}\text { Personal } \\
\text { car }\end{array}$ & $\begin{array}{l}\text { Bus, tram, } \\
\text { underground }\end{array}$ & Train \\
\hline & (I) & (II) & (III) & (IV) & (V) \\
\hline \# Observations & 3,292 & 38,577 & 83,122 & 5,918 & 8,217 \\
\hline Female & $\begin{array}{l}-0.001 \\
(6.1)\end{array}$ & $\begin{array}{l}-0.094^{* * *} \\
(28.5)\end{array}$ & $\begin{array}{l}0.072^{* * * *} \\
(20.6)\end{array}$ & $\begin{array}{l}0.021^{* * *} \\
(14.4)\end{array}$ & $\begin{array}{c}0.003^{* * *} \\
(5.3)\end{array}$ \\
\hline Part-time worker & $\begin{array}{l}0.000^{* *} \\
(0.8)\end{array}$ & $\begin{array}{l}0.022^{* * *} \\
(6.8)\end{array}$ & $\begin{array}{l}-0.019^{* * *} \\
(5.7)\end{array}$ & $\begin{array}{l}-0.003^{*} \\
(2.4)\end{array}$ & $\begin{array}{l}0.001 \\
(1.1)\end{array}$ \\
\hline Log hourly wage & $\begin{array}{l}-0.002^{* *} \\
(10.0)\end{array}$ & $\begin{array}{l}-0.125^{* * *} \\
(26.4)\end{array}$ & $\begin{array}{l}0.156^{* * *} \\
(31.4)\end{array}$ & $\begin{array}{l}-0.025^{* * *} \\
(12.3)\end{array}$ & $\begin{array}{c}-0.004^{* * *} \\
(4.6)\end{array}$ \\
\hline Log travel distance & $\begin{array}{l}-0.006^{* * *} \\
(27.9)\end{array}$ & $\begin{array}{l}-0.250^{* * *} \\
(161.3)\end{array}$ & $\begin{array}{l}0.219^{* * *} \\
(122.1)\end{array}$ & $\begin{array}{l}0.009^{* * *} \\
(16.6)\end{array}$ & $\begin{array}{l}0.028^{* * *} \\
(58.3)\end{array}$ \\
\hline Married & $\begin{array}{l}-0.001^{* * *} \\
(7.0)\end{array}$ & $\begin{array}{l}0.009^{* *} \\
(2.8)\end{array}$ & $\begin{array}{l}0.017^{* * *} \\
(5.4)\end{array}$ & $\begin{array}{l}-0.018^{* * *} \\
(12.7)\end{array}$ & $\begin{array}{c}-0.007^{* * *} \\
(11.3)\end{array}$ \\
\hline Manufacturing & $\begin{array}{l}-0.001^{* *} \\
(1.8)\end{array}$ & $\begin{array}{l}0.029 \\
(0.9)\end{array}$ & $\begin{array}{l}-0.181^{* *} \\
(2.8)\end{array}$ & $\begin{array}{l}0.043 \\
(1.4)\end{array}$ & $\begin{array}{l}0.111 \\
(1.2)\end{array}$ \\
\hline Private services & $\begin{array}{l}0.000 \\
(0.1)\end{array}$ & $\begin{array}{l}-0.030 \\
(1.2)\end{array}$ & $\begin{array}{l}-0.177^{* * *} \\
(3.4)\end{array}$ & $\begin{array}{l}0.086^{* *} \\
(2.9)\end{array}$ & $\begin{array}{l}0.121 \\
(1.7)\end{array}$ \\
\hline Public services & $\begin{array}{l}0.001 \\
(1.6)\end{array}$ & $\begin{array}{l}0.074^{* * *} \\
(3.4)\end{array}$ & $\begin{array}{l}-0.228^{* * *} \\
(6.7)\end{array}$ & $\begin{array}{l}0.068^{* * *} \\
(3.3)\end{array}$ & $\begin{array}{l}0.085^{*} \\
(2.0)\end{array}$ \\
\hline $\begin{array}{l}\text { Lower secondary education } \\
\text { (VMBO, MBO 1) }\end{array}$ & $\begin{array}{l}-0.001^{* *} \\
(3.1)\end{array}$ & $\begin{array}{l}0.028^{* * *} \\
(3.5)\end{array}$ & $\begin{array}{l}-0.005 \\
(0.6)\end{array}$ & $\begin{array}{l}-0.018^{* * *} \\
(9.6)\end{array}$ & $\begin{array}{l}-0.004^{*} \\
(2.2)\end{array}$ \\
\hline $\begin{array}{l}\text { Lower tertiary education } \\
\qquad(\mathrm{MBO} 2,3)\end{array}$ & $\begin{array}{l}-0.001^{* * *} \\
(4.3)\end{array}$ & $\begin{array}{l}0.036^{* * *} \\
(4.6)\end{array}$ & $\begin{array}{l}-0.010 \\
(0.3)\end{array}$ & $\begin{array}{l}-0.024^{* * *} \\
(13.9)\end{array}$ & $\begin{array}{l}-0.001 \\
(0.5)\end{array}$ \\
\hline $\begin{array}{l}\text { Lower tertiary education } \\
\qquad(\mathrm{MBO} 4)\end{array}$ & $\begin{array}{l}-0.001^{* *} \\
(3.0)\end{array}$ & $\begin{array}{l}0.076^{* * *} \\
(10.9)\end{array}$ & $\begin{array}{l}-0.047^{* * *} \\
(5.7)\end{array}$ & $\begin{array}{l}-0.029^{* * *} \\
(16.7)\end{array}$ & $\begin{array}{l}0.001 \\
(0.6)\end{array}$ \\
\hline $\begin{array}{l}\text { Higher secondary education } \\
\text { (HAVO, VWO) }\end{array}$ & $\begin{array}{l}0.001 \\
(1.3)\end{array}$ & $\begin{array}{l}0.110^{* * *} \\
(10.9)\end{array}$ & $\begin{array}{l}-0.116^{* * *} \\
(11.7)\end{array}$ & $\begin{array}{l}-0.010^{* * *} \\
(4.4)\end{array}$ & $\begin{array}{c}0.016^{* * *} \\
(4.6)\end{array}$ \\
\hline $\begin{array}{l}\text { Higher tertiary education } \\
\text { (HBO, BA) }\end{array}$ & $\begin{array}{l}0.000 \\
(0.9)\end{array}$ & $\begin{array}{l}0.145^{* * *} \\
(16.4)\end{array}$ & $\begin{array}{l}-0.120^{* * *} \\
(13.6)\end{array}$ & $\begin{array}{l}-0.031^{* * *} \\
(15.8)\end{array}$ & $\begin{array}{l}0.005^{*} \\
(2.4)\end{array}$ \\
\hline $\begin{array}{l}\text { Higher tertiary education } \\
(\mathrm{MA}, \mathrm{PhD})\end{array}$ & $\begin{array}{l}0.001 \\
(1.6)\end{array}$ & $\begin{array}{l}0.255^{* * *} \\
(22.8)\end{array}$ & $\begin{array}{l}-0.266^{* * *} \\
(25.3)\end{array}$ & $\begin{array}{l}-0.017^{* * *} \\
(7.5)\end{array}$ & $\begin{array}{c}0.026^{\text {*** }} \\
(6.4)\end{array}$ \\
\hline Pseudo $R^{2}$ & & & 0.268 & & \\
\hline
\end{tabular}

Notes: $z$-values (in absolute values) are in parentheses. Omitted category when estimating the model was pedestrian. Significance levels of $0.05,0.01$ and 0.001 are denoted by ${ }^{*},{ }^{* *}$ and ${ }^{* * *}$ respectively. Year and age (5-year groups) fixed effects are included.

These results are consistent with the hypotheses formulated in Section 3. Even when controlling for wages, well-educated workers do not only travel more than lower educated, they are also less willing to use the car and other private means of transport, except for the bicycle. The finding that higher educated workers are (ceteris paribus) more likely to take the train supports the view that higher educated workers are better able to use time spent in a train (for either work or leisure). The finding that workers with higher wages are more likely 
to use the car is consistent with the view that there is a positive relation between income and speed. As was the case for the regressions on commuting distance and time from the previous section, an analysis of the time specific effect showed that the choice for different modes of transport remained fairly constant between 2000 and 2008.

\section{Conclusion}

The level of education of individuals has almost always been treated as a statistical control in the empirical literature on commuting, but it rarely has been the object of a specific analysis and discussion. This paper has made an attempt to analyze the effects of education on travel behavior of Dutch employees, trying also to understand the difference between higher levels of education and high wages, which are often much correlated. Results show that, even after controlling for their wage, commutes of highly educated workers are substantially longer compared to commutes of lower educated workers. At the same time, we find strong interaction effects between wages and education on commuting time and duration. For lower educated workers, we find a strong relation between wages and commuting distance and time. For higher educated workers this relation is less strong, while it has almost no effect for university graduates. There is no effect of education on the speed of commuting. Across different specifications, the effect of education on commuting distance is similar to the effect on commuting time. In addition, higher educated workers are more frequent users of public transport and of bicycles.

Many factors could explain observed heterogeneity in commuting patterns between lower and higher educated workers. Even though future research will need to address this more thoroughly, the empirical evidence in this paper provides some preliminary insights.

First of all, we find that higher educated workers are relatively more likely to commute towards agglomerated areas and areas that pay higher wages compared to less educated. As has been shown by, for example, Groot et al. (2011), there is substantial sorting of employees across regions, whereby higher educated workers are relatively more likely to work in locations with a high economic density and productivity. Productivity thus attracts high skilled employment to the cities. Supply of housing and heterogeneity in demand for housing, on the other hand, tend to have the opposite effect. Because higher educated workers have on average relatively higher incomes. The largest Dutch cities (that are the most attractive for higher educated employees as a location to work because of productivity advantages) are characterized by a relatively high share of social housing. This is likely to - at least to some 
extent - explain the finding that higher educated individuals are relatively more likely to commute from a low density municipality towards a high density municipality. Furthermore, higher educated workers are more often house owners, which reduces their labor mobility.

Sorting of employees is not only taking place due to differences in productivity or the kind of houses people want to live in, but also due to differences in the willingness to pay for amenities. If, at a given density and average productivity level, housing prices go up, lower educated workers are more likely to commute towards this municipality than from. For higher educated workers this is opposite. Furthermore, whereas it is rather unlikely for lower educated workers to commute between larger cities, there are many higher educated workers that commute even between the largest Dutch agglomerations.

A possible explanation for both the finding that higher educated workers commute more than lower educated, and the finding that higher educated workers are more likely to commute between the largest cities, are relatively higher search frictions. Because higher educated workers perform generally more specialized work, the probability to find a good match close to the current residence location is relatively low. Such specialized workers are therefore relatively more likely to accept a job offer further away, giving them the choice between commuting or moving. Particularly excess commutes is an indication for the existence of search frictions. The large bidirectional flows of highly educated commuters between pairs of cities are likely to be excess commuting (though in theory they could represent local scarcity of certain types of very specialized high skilled labor) is consistent with the view that higher search frictions for high skilled employees causes their commutes to be longer.

The finding that higher educated workers are more likely to commute by train could be explained by, for example, the possibility to carry out part of their work while commuting. However, it is also possible that the locations where higher educated workers are employed are generally closer to a train station. A healthier lifestyle may explain their preference for the use of bicycles. Besides the other mentioned factors, it could be worth considering possible effects on the set of individual's preferences driven by education, which could also affect the disutility associated with the use of non-motorized or non private means of transport. 


\section{References}

Burbidge, S.K., K.G. Goulias and T.G. Kim (2006), 'Travel behavior comparisons of active living and inactive living lifestyles', Proceedings of the 85th Annual Meeting of the Transportation Research Board, January 2006, Washington, D.C.

Combes, P.P., G. Duranton and L. Gobillon (2008), 'Spatial wage disparities: sorting matters', Journal of Urban Economics, 63, pp. 723-742.

Coogan, M.A. (2003), 'Why care about walking?: a celebration of the NHTS', accessed at http://nhts.ornl.gov/2001/presentations/walking/walking.ppt, August 2003.

De Groot, H.L.F. (2011), 'Determination of land rents: a simple approach', accessed at http://www.landvalues.nl/, May 2012.

Dieleman, F.M., M. Dijst and G. Burghouwt (2002), 'Urban form and travel behaviour: micro-level household attributes and residential context', Urban Studies, 39, pp. 507-527.

Giuliano, G. (1989), 'New directions for understanding transportation and land use', Environment and Planning A, 21, pp. 145-159.

Giuliano, G. and K.A. Small (1993), 'Is the journey to work explained by urban structure?', Urban Studies, 30, pp. 1485-1500.

Glaeser, E.L. (2011), Triumph of the city: how our greatest invention makes us richer, smarter, greener, healthier, and happier, Penguin Press, New York.

Glaeser, E.L. and A. Saiz (2004), 'The rise of the skilled city', Brookings-Wharton Papers on Urban Affairs, 5, pp. 47-94.

Groot, S.P.T., H.L.F. De Groot and M.J. Smit (2011), Regional wage differences in the Netherlands: micro-evidence on agglomeration externalities, TI Discussion Paper 2011-050/3, Amsterdam/Rotterdam.

Gutiérrez-i-Puigarnau, E. and J. Van Ommeren (2010), 'Labour supply and commuting', Journal of Urban Economics, 68, pp. 82-89.

Holzer, H. (1987), 'Informal job search and black youth unemployment', American Economic Review, 77, pp. 446-452.

Hood, J.K. (1999), 'The determinants of home ownership: an application of the human capital investment theory to the home ownership decision', The Park Place Economist, 7, pp. 40-50.

Lee, B.S. and J.F. McDonald (2003), 'Determinants of commuting time and distance for Seoul residents: the impact of family status on commuting of women', Urban Studies, 40, pp. 12831302.

Levinson, D. and A. Kumar (1995), 'Activity, travel, and the allocation of time', Journal of the American Planning Association, 61, pp. 458-470.

Manning, A. (2003), 'The real thin theory: monopsony in modern labour markets', Labour Economics, 10, pp. 105-131.

OECD (2010), Economic surveys: Netherlands, Paris. 
Öhman, M. and U. Lindgren (2003), 'Who is the long-distance commuter? Patterns and driving forces in Sweden', Cybergo: European Journal of Geography, 243, pp. 2-24.

Ory, D.T., P.L. Mokhtarian, L.S. Redmond, I. Salomon, G.O. Collantes and S. Choo (2004), 'When is commuting desirable to the individual?', Growth and Change, 35, pp. 334-359.

Papanikolaou, G. (2006), 'Spatial and individual influence on commuting behaviour in Germany', Paper presented at the $46^{\text {th }}$ Congress of the European Regional Science Association (ERSA), August 30 - September 3, Volos (Greece).

Parent-Thirion, A., E.F. Macias, J. Hurley and G. Vermeulen (2007), Fourth European working conditions survey, European Foundation for the Improvement of Living and Working Conditions, Luxembourg.

Prashker, J., Y. Shiftan and P. Hershkovitch-Sarusi (2008), 'Residential choice location, gender and the commute trip to work in Tel Aviv', Journal of Transport Geography, 16, pp. 332-341.

Rouwendal, J. (2004), 'Search theory and commuting behavior', Growth and Change, 35, pp. 391418.

Rouwendal, J. and P. Nijkamp (2004), 'Living in two worlds: a review of home-to-work decisions', Growth and Change, 35, pp. 287-303.

Rouwendal, J. and J.W. Van der Straaten (2004), 'Dual earners, urban labour markets and housing demand', in R. Capello and P.Nijkamp (eds), Urban Dynamics and Growth, Elsevier, Amsterdam.

Shen, Q. (1998), 'Location characteristics of inner-city neighborhoods and employment accessibility of low-wage workers', Environment and Planning B, 25, pp. 345-365.

Shen, Q. (2000), 'Spatial and social dimensions of commuting', Journal of the American Planning Association, 66, pp. 68-82.

Van Ommeren, J. and P. Rietveld (2005), 'The commuting time paradox', Journal of Urban Economics, 58, pp. 437-454.

Van Ommeren, J. and J.W. Van der Straaten (2008), 'The effect of search imperfections on commuting behaviour: evidence from employed and self-employed workers', Regional Science and Urban Economics, 38, pp. 127-147.

Van Ommeren, J. and M. Van Leuvensteijn (2005), 'New evidence of the effect of transaction costs on residential mobility', Journal of Regional Science, 45, pp. 681-702.

Vance, C. and R. Hedel (2008), 'On the link between urban form and automobile use: evidence from German survey data', Land Economics, 84, pp. 51-65.

Venhorst, V., J. Van Dijk and L. Van Wissen (2011), 'An analysis of trends in spatial mobility of Dutch graduates', Spatial Economic Analysis, 6, pp. 57-82.

Wilson, W. (1987), The truly disadvantaged, Chicago University Press, Chicago.

Yapa, L., M. Polese and J. Wolpert (1971), 'Interdependences of commuting, migration, and job site relocation', Economic Geography, 47, pp. 59-72. 